\title{
The Effect of Financial Literacy and Financial Inclusion on Retirement Planning
}

\author{
Rahmat Aryo Baskoro, Rensi Aulia
}

\begin{abstract}
This study aims to determine the effect of financial literacy and financial inclusion on retirement planning. This study used a quantitative method with 236 respondents and processed by the method of multiple linear regression analysis. The results of the study show that financial literacy and financial inclusion have a significant effect on retirement planning, means that the higher financial literacy and financial inclusion of a person, the better their retirement planning. In addition, the results of the study showed that respondents were dominated by moderate financial literacy levels with a percentage of $55.08 \%$, moderate financial inclusion levels with a percentage of $57.20 \%$ and high retirement planning levels with presentations of $52.54 \%$ of the total respondents. Researchers also conduct additional research by choosing one of the demographic factors, which is monthly income. The results that monthly earnings also influence retirement planning where the higher a person's monthly income, the better their retirement planning.
\end{abstract}

Keywords : Financial Literacy, Financial Inclusion, Financial Behavior, Financial Knowledge, Financial Decisions, Retirement Planning

DOI : https://doi.org/10.30596/ijbe.v1i1.3442

JEL Classification : G00, G1, G23, G32

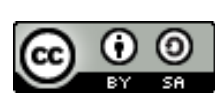

Published by IJBE, Indonesia | Copyright (C) 2019 by the Author(s) | This is an open access article distributed under the Creative Commons Attribution License http://creativecommons.org/licenses/by/4.0), which permitsunrestricted use, distribution, and reproduction in any medium, provided the original work is properly cited.

Cite this article as:

Baskoro, R. A., \& Aulia, R. (2019). The Effect of Financial Literacy and Financial Inclusion on Retirement Planning. International Journal of Business Economics (IJBE), 1(1), 49-58.

\footnotetext{
Department of Management, Faculty of Economics and Business, Universitas Indonesia Jl. Prof. DR. Sumitro Djojohadikusumo, Kota Depok, West Java, Indonesia

*Corresponding Author: aryobaskoro.feui@gmail.com
} 


\section{IJBE}

International Journal of Business Economics, 1(1), 1-19, September 2019

http://jurnal.umsu.ac.id/index.php/ijbe

eISSN 2686-472X

\section{INTRODUCTION}

To achieve financial well-being, each individual is encouraged to make choices that will determine financial goals in every aspect of life. With the presence of various demographic, social and economic trends such as the baby boom and increasing life expectancy, changes in income and retirement planning, also the more and complex financial products offered, financial literacy is increasingly recognized. Both government and financial institutions, also has an understanding of financial literacy needs in the community, so they can avoid mistakes in making financial decisions and participate in building a better financial future (Raaij, 2016). The composition of the population in Indonesia is dominated by residents of productive age and is expected to continue to dominate for the next twenty years. This is referred to as a bonus demographic because the population with a large productive age is capital to realize high and sustainable economic growth.

The existence of pension funds in Indonesia is still not as popular as other investment instruments. This is due to the view of the people who think that pension funds are only obtained by workers who work in the government sector only such as Civil Servants (PNS), Employees of State-Owned Enterprises (BUMN), army, police and so on. In fact, pension funds can also be submitted by individuals or corporations through the Financial Institution Pension Fund (DPLK). It is known that in 2016 from the results of the National Survey on Financial Literacy and Inclusion, the financial literacy index of pension funds was only 10.91 percent and ironically the financial inclusion index of pension funds was only 4.66 percent. From this figure, it is sufficient to prove that the public's understanding of the pension program is still relatively low. This has become a concern of various parties, especially the government, to increase public awareness of the importance of pension funds through financial literacy and inclusion.

According to data from the Central Statistics Agency per 2017, the number of formal workers in Indonesia reached 73.98 million workers. However, only 49.95 million workers were recorded as participants in pension plans, both DPLK, DPPK and DPBK. Then the new pension fund participants reach 66 percent and the rest are still not protected against old age risks. In addition to the government's efforts to require workers to take part in an old age guarantee program, each individual needs to have awareness to prepare it. Researchers have realized the influence of financial literacy on how someone makes economic decisions. Households that have high financial literacy will have better financial planning and pensions (Lusardi \& Mitchell, 2007).

For each country, financial literacy is considered important for the community because the higher the financial literacy that is owned by the community influences financial decisions that are taken more optimally and influences every aspect of society. Many studies have shown that people who have financial literacy will have an impact on the formation of financially independent communities, the reduced risk in each financial service sector, and support for the government in achieving financial prosperity for each individual. Because the Financial Services Authority made a National Survey of Indonesian Financial Literacy and Inclusion, this study will also include variables of financial inclusion. The level of financial inclusion illustrates how people have access to financial products and services provided by financial institutions. Financial inclusion is considered important because it is expected to increase opportunities for people's lives. However, ironically financial inclusion in Indonesia is still relatively slow in recent years, it was reported from the results of a survey conducted by the Indonesian Financial Services Authority. 


\section{IJBE}

International Journal of Business Economics, 1(1), 1-19, September 2019

http://jurnal.umsu.ac.id/index.php/ijbe

eISSN 2686-472X

\section{Retirement Planning}

Pensions are withdrawals for the completion of work or career periods accompanied by changes in the value of resources and income. Furthermore, retirement is the process of separating individuals from their jobs, where in carrying out their roles someone gets a salary (Seay, et al., 2016).

One of the keys to being able to successfully retire is the preparation that is carried out while still productive. Individuals who have made plans for their retirement tend to be more successful in adapting to changes in their lives. Retirement preparation is defined as an investment effort made by individuals who are still working for their welfare in retirement (Donaldson, et al., 2010).

The retirement planning program according to the Financial Services Authority is as follows the Defined Benefit Pension Program is a pension plan whose benefits are stipulated in a Pension Fund Regulation or other pension program that is not a Defined Contribution Pension Program. The defined benefit pension plan is only applied to the Employer Pension Fund. The amount of the pension benefit is stipulated in the Pension Fund Regulations with a certain formula. The value can be different between one company and another.

The Defined Contribution Pension Program is a pension plan whose contributions are stipulated in a Pension Fund Regulation and all contributions and development results are recorded in the account of each Participant as a Pension Benefit. The Defined Contribution Pension Program is a pension plan that is linked to contributions paid by the employer company and participant contributions (usually deducted directly from the participants' salary by the Company and deposited to the Pension Fund), then the funds are invested in investment products (money market, and/or capital market) according to applicable rules.

The type of retirement planning according to Law No. 11 of 1992 is as follows: DPKK is a pension fund formed by a person or entity that employs employees, as the founder, to hold a Defined Benefit Pension Program or a Defined Contribution Pension Program, for the benefit of some or all employees as participants, and which creates obligations to employers (Article 1 Paragraph 2 Law No. 11 of 1992). DPLK is a pension fund established by a Bank or life insurance company to establish a defined contribution pension plan for individuals, both for employees of employers and independent workers who are separate from the Employer Pension Fund for employees of the Bank or the relevant Life Insurance Company (Article 1 Paragraph 4 Law No. 11 of 1992).

\section{Financial Literacy}

Financial literacy is a knowledge and ability possessed by someone in a financial context. Things that are included in the financial context here are knowledge about personal finance, ability to manage money, knowledge about credit, savings, investment, and risk. To determine the level of financial literacy sufficient, one must collect and process financial information which includes the context of interest rates, risk management, inflation, and asset management (Lusardi \& Mitchell, 2007). The level of financial literacy in Indonesia is divided into 4 parts by the Financial Services Authority (OJK), namely:

1. Well Literate, having knowledge and beliefs about financial service institutions and financial service products, including features, benefits and risks, rights and obligations related to financial products and services, and having skills in using financial products and services. 


\section{IJBE}

International Journal of Business Economics, 1(1), 1-19, September 2019

http://jurnal.umsu.ac.id/index.php/ijbe

eISSN 2686-472X

2. Sufficient Literate, having knowledge and beliefs about financial service institutions and financial products and services, including features, benefits and risks, rights and obligations related to financial products and services.

3. Less Literate, only has knowledge of financial services institutions, financial products and services.

4. Not Literate, lacks knowledge and confidence in financial service institutions and financial products and services, and does not have the skills to use financial products and services.

\section{Financial Inclusion}

Financial inclusion is a process to ensure access to financial products and services needed by all sections of society including vulnerable groups such as low-income groups at affordable and fair costs by mainstream institutional players. The aim of financial inclusion is to make easy access to financial services for large populations of underprivileged countries.

Financial inclusion, defined as the use of formal financial services, greatly determines economic development. Non-excluded individuals can financially invest in education and launch businesses, and this contributes to poverty reduction and economic growth. Financial inclusion provides individuals with the possibility of having a safe place to save for the future and can also promote financial stability, because high bank deposit usage rates contribute to a more stable deposit base for banks in difficult times (Han, \& Melecky, 2013).

According to the United Nations, the main objectives of financial inclusion are as follows: Access at affordable costs for all households and companies in a variety of bankable financial services including savings, short and long-term loans, leasing and factoring, mortgages, insurance, pensions, payments, local money transfers and international money transfers. A sound institution, guided by an appropriate internal management system, industry performance standards and market performance monitoring. Financial and institutional sustainability as a means to provide access to financial services from time to time. Many financial service providers, wherever possible, can be cost-effective and a variety of alternatives for customers that can include a number of combinations of private, non-profit and healthy public service providers. Increasing access to financial services will help overcome a number of obstacles that have hampered growth both at the individual and state level.

Researchers have realized the influence of financial literacy on how someone makes economic decisions. Households that have high financial literacy will have better financial planning and pensions (Lusardi \& Mitchell, 2007).

World Bank revealed that there are at least four types of formal financial services that are considered vital for people's lives, namely fund storage services, credit services, payment system services, and insurance including pension funds. These four aspects are the basic requirements that every community must have to get a better life. Increasing public access to financial institutions is certainly a complexity problem that requires cross-sectoral coordination involving banking authorities, non-bank financial institutions, and other ministries or agencies that are concerned with poverty alleviation efforts, so that comprehensive and comprehensive policies are needed in a national inclusion strategy finance.

\section{RESEARCH METHOD}

This study has three variables, namely two independent variables and one dependent variable. These three variables are measured using different measuring instruments. The first independent variable is financial literacy which will be measured using a Financial Literacy measurement tool adapted from the research of Rooij (2011), Klapper (2013). This 


\section{IJBE}

International Journal of Business Economics, 1(1), 1-19, September 2019

http://jurnal.umsu.ac.id/index.php/ijbe

eISSN 2686-472X

measurement tool aims to see the extent of respondents' understanding and ability to manage their finances.

In addition to the independent variables there are also dependent variables. In this study the dependent variable is retirement planning which is measured by using three items, namely asking whether the respondent has calculated costs after retirement, has a plan for pension funds and the type of pension funds that the respondent has.

There are three approaches in explaining the type of research that is reviewed from the application, purpose, and how to obtain data (Kumar, 2019). First, in terms of its application, this research includes applied research because it can provide information about a particular phenomenon or problem. Second, in terms of objectives, this study is a correlational study because this study aims to find the existence or absence of relationships / associations / linkages between two or more situations. Judging from the way of obtaining information, this research includes quantitative research because the data obtained is in the form of numbers and processed with statistical calculations. Quantitative research is also called structured research because everything related to the research process has been determined by researchers from the beginning before the research was carried out.

There are three approaches in explaining research design, namely in terms of the amount of contact with the sample, the time frame, and the nature of the study (Kumar, 2019). First, in terms of the number of contacts with the sample, this study included a cross sectional study that is a situation when data is taken in one population at a given time that can be used to find out about the prevalence of a particular phenomenon, situation, problem, attitude or issue. Second, in terms of the time frame, this study is retrospective because it examines the phenomenon or problem that has occurred. Third, in terms of the nature of the research, this research is non-experimental because there is no manipulation and occurs in natural settings.

There are two characteristics of respondents in this study as follows: 1 . Has the age of 17 years, researcher used productive age as research respondents. For this reason, respondents will fill their age in the control data. According to Law No. 13 of 2003 Chapter I article 1 paragraph 2 states that labor is anyone who is able to do work to produce goods or services both to meet their own needs and for the community. 2. Have been / are working, the respondents of this study were employees who had worked. For this reason, respondents will be asked to fill out their type of work. Employees who work are assumed to have a pension fund paid through Employment BPJS.

The total sample in this study amounted to 236 people. This is consistent with the opinion of Fraenkel and Wallen (1993) who suggested that the minimum sample size in correlational research should ideally use a sample of at least 50 people. In addition, the larger the number of samples, the more obtained results will be due to the smaller variance errors that appear on the data.

In this study, researchers used the technique of taking online questionnaire data. The questionnaire was disseminated using online methods to make it easier to get participants who could not be found directly. The researcher carried out data collection using a questionnaire because it was more effective in saving time to cost, and allowing a wider range of participants. In addition, the questionnaire also guarantees the confidentiality of identity for each participant. So that participants are expected to be able to give real answers (Kumar, 2019).

The researcher used a questionnaire containing a measuring instrument of each variable that was made into a questionnaire containing measuring instruments for each variable which 


\section{IJBE}

International Journal of Business Economics, 1(1), 1-19, September 2019

http://jurnal.umsu.ac.id/index.php/ijbe

eISSN 2686-472X

was made into an online questionnaire. The measuring instruments included in this questionnaire are as follows.

The financial literacy measurement adapted from previous studies, namely Rooij (2011), Klapper (2013) and Chen is a maximum performance test, that is, each question has the right and wrong answers. Financial literacy can be measured based on four dimensions, namely general financial knowledge, ability to calculate interest rates, understanding of inflation and understanding of risk diversification.

This measuring instrument consists of 13 question items. Each question is in the form of multiple choices with different commands. Each question is given several alternative answers where there is only one correct choice. To find out the score of each respondent, the researcher conducted a scoring by matching the respondent's answer with the answer key. Each correct answer is given a score of 1 and the wrong answer is given a score of 0 . The scoring results of this financial literacy measure can be classified according to several categories, namely: Low financial literacy rate: a total score of 0 to 6, Medium financial literacy rate: total score 7 to 10 , High financial literacy level: total score 12 to 13.

Financial inclusion measuring instruments which are known from eight items. Respondents were asked to answer whether they had sufficient access to financial products. Scores are given to the ability of respondents to access financial products.

This measuring instrument consists of 8 question items. To find out the score of each respondent, the researcher scores with the answer "yes" given a score of 1 and the answer "no" is given a score of 0 . The scoring results of the financial inclusion measure can be classified according to several categories, namely: Low financial inclusion rates: a total score of 0 to 2, Medium financial inclusion level: total score 3 to 5, High financial inclusion rate: total score 6 to 8

Retirement planning by respondents is known from four items. Respondents were asked to answer whether they had calculated the costs after retirement, had a plan for the pension to be received. If the respondent already has it, then the respondent is asked to specify whether the type of pension fund is. Scores are given to respondents' readiness for retirement planning for investment.

This measuring instrument consists of 4 question items. To find out the score of each respondent, the researcher scores with a "yes" answer given a score of 1 and a "no" answer is given a score of 0 . Except for the last question where the participant was asked what the old age guarantee program was. Values will be given a large number of products owned by participants, but if there are answers where inherent and mandatory old-age insurance programs (such as retired companies) will not be calculated to avoid biased results because it is a coercion and not of personal will. The scoring results of these financial inclusion gauges can be classified according to several categories, namely: Low retirement planning level: total score 0 to 1 , Moderate retirement planning level: total score 2 to 3, High retirement planning level: total score $\geq 4$

Data collected for 6 days is 298 data. The researcher then eliminated according to the characteristics of the respondents who had been determined and the completeness of the respondents filled out the questionnaire. From the process of elimination, the total data is 236 data that matches the characteristics of the study. After that, the researcher processed the data using SPSS software (Statistical Package for the Social Sciences) version 24.0.

The statistical analysis technique used in this study to process research data is as follows: Descriptive statistic is used to obtain an overview of the characteristics of respondents in this study such as gender, domicile (residence), age, education, employment, income per month. In 


\section{IJBE}

International Journal of Business Economics, 1(1), 1-19, September 2019

http://jurnal.umsu.ac.id/index.php/ijbe

eISSN 2686-472X

addition, this technique is also to find out the frequency distribution (minimum and maximum), mean (mean) and standard deviation, Multiple Regression is used to see whether there is an influence given by some independent variables (financial literacy and financial inclusion) on the dependent variable (retirement planning). This technique is used to analyze how much the retirement planning variable can be predicted by financial literacy and financial inclusion variables.

\section{RESULTS AND DISCUSSION}

From the total of 298 respondents, the researcher then proceeded to eliminate the process according to the characteristics of the respondents. After going through the process of elimination, the number of respondents whose data can be processed becomes 236 data. The following are data that will be processed using statistical analysis techniques derived from 236 respondents.

Table 1. Descriptive Analysis Gender Respondents

\begin{tabular}{ccccccc}
\hline \multirow{2}{*}{ Gender } & Male & 94 & 39.83 & 8.78 & 4.96 & 3.37 \\
& Female & 142 & 60.17 & 8.88 & 4.82 & 3.13 \\
\hline
\end{tabular}

From the table it is known that as many as 94 respondents $(39.83 \%)$ were male and as many as 142 respondents $(60.17 \%)$ were women. When viewed from the average financial literacy, women have higher financial literacy with a value of 8.88 compared to men with a value of 8.78. Then when viewed from the average financial inclusion, men have higher financial inclusion with a value of 4.96 compared to women with a value of 4.82 . And when viewed from its retirement planning average, men have a higher retirement planning with a value of 3.37 compared to women with a value of 3.13 .

This phenomenon occurs with the cultural assumption in Indonesia that men have more responsibility for their families, especially if they have become household heads. That is what makes male retirement planning higher than women.

Table 2. Descriptive Analysis Domicile Respondents

\begin{tabular}{|c|c|c|c|c|c|c|}
\hline \multicolumn{2}{|c|}{$\begin{array}{l}\text { Characteristics of } \\
\text { Respondents }\end{array}$} & \multirow{2}{*}{$\begin{array}{c}\text { Frequency } \\
1\end{array}$} & \multirow{2}{*}{$\begin{array}{c}\begin{array}{c}\text { Percentage } \\
(\%)\end{array} \\
0.42\end{array}$} & \multirow{2}{*}{$\begin{array}{c}\begin{array}{c}\text { Average } \\
\text { Financial } \\
\text { Literacy }\end{array} \\
10.00\end{array}$} & \multirow{2}{*}{$\begin{array}{c}\begin{array}{c}\text { Average } \\
\text { Financial } \\
\text { Inclusion }\end{array} \\
3.00\end{array}$} & \multirow{2}{*}{$\begin{array}{c}\begin{array}{c}\text { Average } \\
\text { Retirement } \\
\text { Planning }\end{array} \\
2.00\end{array}$} \\
\hline Domicile & Banten & & & & & \\
\hline & Jabodetabek & 192 & 81.36 & 9.08 & 5.03 & 3.29 \\
\hline & $\begin{array}{c}\text { Jawa (Non- } \\
\text { Jabodetabek) \& } \\
\text { Bali }\end{array}$ & 25 & 10.59 & 7.80 & 4.20 & 3.12 \\
\hline & Kalimantan & 6 & 2.54 & 8.17 & 5.50 & 3.00 \\
\hline & Sulawesi & 1 & 0.42 & 9.00 & 2.00 & 1.00 \\
\hline & Sumatera & 11 & 4.66 & 7.18 & 3.82 & 2.91 \\
\hline
\end{tabular}

From the table it is known that the domicile of respondents is dominated by Jabodetabek residents as many as 192 respondents $(81.36 \%)$, then the remaining 44 respondents $(18.64 \%)$ are domiciled in Banten, Java (Non-Jabodetabek) \& Bali, Kalimantan, Sulawesi and Sumatra, if seen from its average financial literacy, Banten has a higher financial literacy with a value of 10.00 with a number of 1 respondent but it cannot be compared with the Jabodetabek value of 9.08 with the number of 192 respondents hence the researcher assumes that financial literacy is the highest is the respondent of the Jabodetabek domicile. 


\section{IJBE}

International Journal of Business Economics, 1(1), 1-19, September 2019

http://jurnal.umsu.ac.id/index.php/ijbe

eISSN 2686-472X

From the average financial inclusion, Kalimantan has the highest financial inclusion with a value of 5.50 with a number of 6 respondents but it cannot be compared with Jabodetabek value which is 5.03 with the number of 192 respondents, the researcher assumes that financial inclusion the highest was Jabodetabek domicile respondents.

And the average retirement planning, Jabodetabek respondents have the highest score of 3.29. From these three things, it can be seen that Jabodetabek respondents are superior in financial literacy, financial inclusion and retirement planning. It can be assumed by researchers that Jabodetabek is the center of the capital city of Indonesia where the area is more advanced than other regions.

Table 3. Descriptive Analysis Age Respondents

\begin{tabular}{ccccccc}
\hline \multicolumn{2}{c}{$\begin{array}{c}\text { Characteristics of } \\
\text { Respondents }\end{array}$} & Frequency & $\begin{array}{c}\text { Percentage } \\
(\%)\end{array}$ & $\begin{array}{c}\text { Average } \\
\text { Financial } \\
\text { Literacy }\end{array}$ & $\begin{array}{c}\text { Average } \\
\text { Financial } \\
\text { Inclusion }\end{array}$ & $\begin{array}{c}\text { Average } \\
\text { Retirement } \\
\text { Planning }\end{array}$ \\
\hline Age & $17-21$ & 6 & 2.54 & 8.83 & 4.67 & 3.00 \\
(years) & $22-26$ & 169 & 71.61 & 8.74 & 4.65 & 3.18 \\
& $27-31$ & 25 & 10.59 & 9.60 & 5.64 & 3.76 \\
& $32-36$ & 12 & 5.08 & 8.50 & 4.83 & 2.83 \\
& $37-41$ & 9 & 3.81 & 8.89 & 5.44 & 3.44 \\
& $>41$ & 15 & 6.36 & 8.93 & 5.93 & 3.13 \\
\hline
\end{tabular}

Then in terms of age, it is known that respondents were dominated by the age group of 2226 years as many as 169 respondents $(71.61 \%)$ then the remaining 67 respondents $(28.39 \%)$ came from the age group 17 to 21 years, 27 to more than 41 Year. Age categories 27-31 Years excel in financial literacy averages 8.50, 5.64 financial inclusion average and 3.76 retirement planning. From these results it can be seen that the higher the financial literacy and financial inclusion of the better the retirement planning period.

Table 4. Descriptive Analysis Marital Status Respondents

\begin{tabular}{ccccccc}
\hline \multicolumn{2}{c}{$\begin{array}{c}\text { Characteristics of } \\
\text { Respondents }\end{array}$} & Frequency & $\begin{array}{c}\text { Percentage } \\
(\%)\end{array}$ & $\begin{array}{c}\text { Average } \\
\text { Financial } \\
\text { Literacy }\end{array}$ & $\begin{array}{c}\text { Average } \\
\text { Financial } \\
\text { Inclusion }\end{array}$ & $\begin{array}{c}\text { Average } \\
\text { Retirement } \\
\text { Planning }\end{array}$ \\
\hline Marital & Married & 59 & 25.00 & 9.08 & 5.31 & 3.46 \\
Status & Single & 177 & 75.00 & 8.76 & 4.73 & 3.15 \\
\hline
\end{tabular}

Then for respondents who are married as many as 59 respondents $(25.00 \%)$ and the rest who have not / are not married as many as 177 respondents (75.00\%). From the results above it is known that married respondents have high financial literacy, financial inclusion and retirement planning compared to respondents who have not / are not married. With that, the researchers assume that the status of marriage is also able to influence the three variables because of the demand to prepare for his parents' day with the family.

Table 5. Descriptive Analysis Income per month Respondents

\begin{tabular}{ccccccc}
\hline \multicolumn{2}{c}{$\begin{array}{c}\text { Characteristics of } \\
\text { Respondents }\end{array}$} & Frequency & $\begin{array}{c}\text { Percentage } \\
(\%)\end{array}$ & $\begin{array}{c}\text { Average } \\
\text { Financial } \\
\text { Literacy }\end{array}$ & $\begin{array}{c}\text { Average } \\
\text { Financial } \\
\text { Inclusion }\end{array}$ & $\begin{array}{c}\text { Average } \\
\text { Retirement } \\
\text { Planning }\end{array}$ \\
\hline $\begin{array}{c}\text { Income } \\
\text { per month }\end{array}$ & $\begin{array}{c}\text { Less than IDR } \\
2.000 .000\end{array}$ & 23 & 9.75 & 7.26 & 3.48 & 2.43 \\
& IDR $2.000 .000-$ & 66 & 27.97 & 8.20 & 4.32 & 3.02
\end{tabular}




\section{IJBE}

International Journal of Business Economics, 1(1), 1-19, September 2019

http://jurnal.umsu.ac.id/index.php/ijbe

eISSN 2686-472X

\begin{tabular}{lccccc}
$\begin{array}{l}5.000 .000 \\
\text { IDR } 5.000 .001\end{array}$ & 104 & 44.07 & 9.23 & 4.99 & 3.31 \\
$\begin{array}{c}\text { 10.000.000 } \\
\text { More than IDR } \\
10.000 .001\end{array}$ & 43 & 18.22 & 9.72 & 6.21 & 3.79 \\
\hline
\end{tabular}

And if it is grouped by income per month, it is dominated by groups with income of IDR $5,000.00$ to IDR $10,000,000$ as many as 104 respondents $(44.07 \%)$ and the remaining 132 respondents (55.93\%) have income ranging from <IDR 2,000 .000, IDR 2,000,000 up to IDR $5,000,000$ up to IDR $10,000,001$.

The highest average financial literacy is in the respondents of the monthly income category of more than Rp.10,000.001 which is 9.72. The highest average financial inclusion is in the respondent's monthly income category of more than Rp.10,000,001 which is 6,21 . And the highest retirement planning average is in respondents in the monthly income category of more than Rp.10,000,001, which is 3.79. And from these results it was also proven that the higher the financial literacy and financial inclusion of the better the retirement planning period. It can be assumed that high income people are better able to prepare their retirement planning because they have fulfilled their needs so that they can invest their money better.

Table 6. Multiple Regression Linear Results

\begin{tabular}{ccccc}
\hline Variable & B & Sig & $\mathbf{R}^{\mathbf{2}}$ & $\mathbf{F}$ \\
\hline Financial Literacy & 0,283 & 0,000 & 0,140 & 19,024 \\
Financial Inclusion & 0,159 & 0,017 & 0,140 Planning \\
\hline
\end{tabular}

Based on the table above, it is known that financial literacy and financial inclusion can simultaneously predict retirement planning, with a value of $\mathrm{r} 2=0.140$ significant $(\mathrm{F}=19.024$, $\mathrm{p}<0.05$ ), which means that $14.0 \%$ retirement planning can be explained as a whole by variables financial literacy and financial inclusion, while $86.0 \%$ retirement planning is explained by other factors. So it can be said that the higher the financial literacy and financial inclusion of a person, the better in making retirement planning.

From the results of the regression test can also be seen the most influential variables on retirement planning. To find out it can be seen from the larger $\beta$ value. From the table above shows that financial literacy has a greater value. This shows that financial literacy has a greater influence than financial inclusion on retirement planning.

Financial literacy has a value of $\beta 0.283$ which means that every 1 point increase in the total financial literacy score is followed by an increase of 0.283 on retirement planning. Positive values indicate the higher a person's financial literacy, the better in making retirement planning. Financial inclusion has a value of $\beta 0.159$ which means that every 1 point increase in the total financial inclusion score is followed by an increase of 0.159 on retirement planning. Positive values indicate the higher one's financial inclusion, the better in making retirement planning. The characteristics of the respondents who were not evenly distributed could be caused by accidental sampling techniques which made the researchers unable to control who could be the research respondents.

\section{CONCLUSION}

This study aims to determine the effect of financial literacy and financial inclusion on retirement planning. Based on the results of the research described in the previous chapter, the conclusions from this study are: There is a significant effect of financial literacy on retirement planning and there is a significant effect of financial inclusion on retirement planning. It can be 


\section{IJBE}

International Journal of Business Economics, 1(1), 1-19, September 2019

http://jurnal.umsu.ac.id/index.php/ijbe

eISSN 2686-472X

concluded that the better financial literacy and financial inclusion of a person, the better in preparing retirement planning.

The researcher has several suggestions that can be used, including: The next researcher uses this research as a reference by exploring the things that have not been identified in this study such as cultural factors in Indonesia. Workers who are about to retire to be able to plan their finances by increasing their financial literacy in order to increase financial inclusion that has an impact on retirement planning. Pension fund managers and financial planners to provide financial knowledge so that pension funds can be used as well as possible. The government can improve financial literacy and inclusion to improve the welfare of the community, especially those who will retire

Limitations in this study are: The data used are primary data from the respondents of the study, amounting to 236 respondents with a distribution that is less evenly distributed in each region. Research respondents are not limited to demographic factors such as education, employment, income, marital status, and domicile. and research does not explore the cultural differences in Indonesia with the countries of origin of the reference journals that allow for different law-forces and so on.

\section{RERERENCES}

Chen, H., \& Volpe, R. P. (1998). An analysis of personal financial literacy among college students. Financial services review, 7(2), 107-128. (references)

Donaldson, T., Earl, J. K., \& Muratore, A. M. (2010). Extending the integrated model of retirement adjustment: Incorporating mastery and retirement planning. Journal of Vocational Behavior, 77(2), 279-289.

Han, R., \& Melecky, M. (2013). Financial inclusion for financial stability: access to bank deposits and the growth of deposits in the global financial crisis. The World Bank.

Kumar, R. (2019). Research methodology: A step-by-step guide for beginners. Sage Publications Limited.

Lusardi, A., \& Mitchell, O. S. (2007). Financial literacy and retirement planning: New evidence from the Rand American Life Panel. Michigan Retirement Research Center Research Paper No. WP, 157.

Seay, M., Kim, K. T., \& Heckman, S. (2016). Exploring the demand for retirement planning advice: The role of financial literacy. Financial Services Review, 25(4), 331-350.

Van Raaij, W. F. (2016). Understanding Consumer Financial Behavior: Money Management in an Age of Financial Illiteracy. Springer. 